\title{
ANALISIS MODEL ALTMAN, GROVER, DAN ZMIJEWSKI DALAM MEMPREDIKSI FINANCIAL DISTRESS PERUSAHAAN PADA INDUSTRI MANUFAKTUR DI INDONESIA
}

\author{
Luthfi Jauharotul Husna \\ Universitas Islam Negeri Walisongo \\ email: luppyhusna29@gmail.com
}

\begin{abstract}
This research was conducted to analyze the model altman score, grover score, zmijewski score, in predicting financial distress in the manufacturing industry. This type of research in this research is quantitative with descriptive methods. The object of this research is a company that has been delisted from the Indonesia Stock Exchange in the 2015-2018 period. The object-taking technique in this study was purposive sampling, amounting to 16. The results of this study indicate that the Altman model has an accuracy rate of 25\%, Grover has an accuracy rate of $6.25 \%$, Zmijewski has an accuracy rate of 50\%. From the three bankruptcy analysis models used in this study it can be concluded that the Zmijewski model is best used as a bankruptcy detector with an accuracy rate of 50\%. This is because a company that goes bankrupt has a tendency to generate a small net capital of its total assets, the company's ability to generate profit before interest and taxes from its assets is getting smaller, the lower the level of company sales using all of its assets, and the less likely the profit before tax can be cover current debts owned by the company.
\end{abstract}

Keywords: Altman, Grover, Zmijewski, Financial Distress

\section{PENDAHULUAN}

Financial Distress akan dialami pada sebuah perusahaan sebelum terjadinya kebangkrutan. Di mana Financial Distress adalah sebuah perusahaan dalam situasi kritis ekonomi yang mana perusahaan akan mengalami kerugian karena dianggap tidak mampu memenuhi kewajibannya saat sudah jatuh tempo. Hal seperti itu yang harus diwaspadai pihak manajemen. Pihak manajemen sebaiknya mengambil tindakan agar perusahaan tidak dalam posisi tersebut.

Financial Distress timbul disebabkan oleh berbagai situasi hingga perusahaan dalam posisi kesulitan keuangan. Menurut Fajriah (2015), Managing Director IMF Christine Lagarde saat ini negara Indonesia berada di sisi yang kurang menguntungkan dari pergeseran ekonomi global. Perlambatan ekonomi China memiliki pengaruh yang cukup kuat dalam memberikan dampak negatif maupun positif terhadap perekonomian di Indonesia. Hal ini dikarenakan China merupakan salah satu negara yang menjadi mitra utama Indonesia, sehingga perlambatan pertumbuhan ekonomi dan pengetatan likuiditas China akan berdampak besar terhadap perekonomian Indonesia.

Perusahaan didirikan dengan tujuan untuk menghasilkan keuntungan dan berkembang secara pesat dan stabil dalam jangka panjang, selain itu setiap perusahaan juga memiliki harapan agar tidak mengalami likuidasi. Akan tetapi pada kenyataanya ungkapan seperti yang di atas belum bisa selalu terjadi dengan baik sesuai yang diharapkan. Prusahaan yang sudah berjalan dalam jangka waktu 
lama seringkali mengalami kesulitan keuangan hingga berujung pada kondisi collapse (bangkrut) hingga terpaksa gulung tikar. Gejala-gejaja kebangkrutan perlu dinalisis guna untuk antisipasi terjadinya kondisi collapse pada suatu perusahaan dimasa mendatang. Dalam penelitian ini cara yang dilakukan untuk mengantisipasi bangkrutnya perusahaan dimasa mendatang ialah dengan melakukan analisis rasio-rasio keuangan perusahaan dengan model tertentu. Hal ini dilakukan mengingat banyaknya kejadian terjadinya collapse (bangkrut) sebuah perusahaan yang pernah dialami oleh perusahaan yang ada di Indonesia. Setiap perusahaan diwajibkan harus selalu waspada terhadap gejala-gejala kebangkrutan yang mungkin dapat muncul. Ketika sebuah perusahaan dinyatakan bangkrut, maka perusahaan tersebut tidak memiliki pilihan lain selain menghentikan seluruh kegiatan usahanya.

Beberapa faktor perusahaan yang mengalami financial distress dapat terjadi jika perusahaan tersebut memiliki kinerja yang menunjukkan laba operasi negatif, nilai buku ekuitas negatif, dan perusahaan telah melakukan merger. Kesulitan likuiditas juga bisa menjadi salah satu tanda dari financial distress, perusahaan yang mengalami kesulitan likuiditas biasanya ditunjukkan dengan semakin turunnya kemampuan perusahaan dalam memenuhi kewajibannya kepada kreditur.

Menurut Atmini dan Wuryana (2005), suatu konsep luas yang terdiri dari beberapa situasi dimana suatu perusahaan menghadapi masalah kesulitan keuangan disebut sebagai perusahaan yang dinyatakan collaps. Financial distress ada suatu perusahaan dapat dimaknai sebagai keluarnya masalah yang terjadi di awal perusahaan yang mengalami collaps terhadap penurunan kondisi keuangan yang terjadi sebuah perusahaan, atau juga kondisi dimana perusahaan tersebut mengalami kejadian kebangkrutan ataupun likuidasi.

Financial Distress dapat terjadi karena adanya pengaruh dari dalam perusahaan sendiri (internal) maupun dari luar perusahaan (eksternal). Damodaran menyatakan, faktor penyebab terjadinya financiall distress dari dalam perusahaan lebih bersifat mikro yaitu kesulitan arus kas, besarnya jumlah hutang, kerugian dalam kegiatan operasional perusahaan selama beberapa tahun. Jika sebuah perusahaan mampu menutupi atau menanggulangi faktor internal tersebut, belum tentu perusahaan tersebut dapat terhindar dari financial distress karena masih terdapat faktor eksternal perusahaan yang menyebabkan financial distress. Faktor eksternal dapat berupa kebijakan pemerintah yang dapat menambah beban usaha yang ditanggung perusahaan, misal tarif pajak yang meningkat yang dapat menambah beban perusahaan. Selain itu juga, masih ada kebijakan suku bunga pinjaman yang meningkat, menyebabkan beban bunga yang ditanggung perusahaan tersebut meningkat.

Prediksi Financial Distress bisa dilakukan oleh pihak internal perusahaan, seperti:

1. Pemberi pinjaman, kaitannya adalah pengambilan keputusan apakah akan memberikan suatu pinjaman dan menentukan kebijakan untuk mengawasi pinjaman yang telah diberikan.

2. Pemerintah, model financial distress juga penting bagi pemerintah dalam anti trust regulation. Pemerintah juga mempunyai tanggungjawab mengawasi kesanggupan membayar utang dan menstabilkan perusahaan individu, oleh karena itu diperlukan model prediksi financial distress untuk mengetahui kesanggupan perusahaan membayar hutang dan menilai kestabilan perusahaan. 
3. Auditor, model prediksi financial distress dapat menjadi alat yang berguna bagi auditor dalam membuat penilaian going concern suatu perusahaan.

4. Manajemen, apabila perusahaan mengalami kebangkrutan maka perusahaan akan menanggung biaya langsung (fee akuntan dan pengacara) dan biaya tidak langsung (kerugian penjualan ata kerugian paksa akibat ketepatan pengadilan).

Kebangkrutan itu sendiri dapat dilihat dan diukur melalui laporan keuangan. Laporan keuangan yang telah diterbitkan oleh perusahaan tersebut merupakan salah satu dari sumber informasi mengenai posisi keuangan perusahaan, kinerja serta perubahan posisi keuangan yang sangat berguna sebagai pendukung pengambilan keputusan yang tepat, data keuangan juga harus dikonversi menjadi informasi yang berguna dalam pengambilan keputusan yang ekonomis.

\section{KAJIAN LITERATUR}

Menurut penafsiran Alimiansyah dan Padji, kebangkrutan sebagai pernyataan dimana kondisi yang dapat menunjukkan jalannya suatu usaha yang sangat kritis (genting) hingga pada akhirnya suatu usaha tersebut berada pada posisi colapse. Kebangkrutan dalam berusaha telah diartikan dengan berbagai cara untuk mendapatkan pernyataan yang jelas tentang masalah keuangan yang dihadapi oleh suatu perusahaan. Munawir menyebutkan bahwa resiko kegagalan keuangan dapat diartikan bahwa perusahaan tersebut tidak mampu dalam membayar kewajibannya pada saat jatuh tempo yang bisa menyebabkan perusahaan mengalami kebangkrutan atau bisa menyebabkan terjadinya perjanjian khusus dengan kreditur untuk mengurangi atau menghapus utangnya.
Altman Score, menurut Hanafi model Altman Z-Score yakni salah satu model prediksi kebangkrutan denngan tingkat ketepatan prediksi kebangkrutan sebesar 94\% untuk model pertama Atlman, dan 95\% untuk model Alman yang telah direvisi dapat memprediksi keadaan perusahaan makanan dan minuman di Bursa Efek. Z-Score adalah skor yang ditentukan dari hitungan standart kali nisbah-nisbah keuangan yang menunjukkan tingkat kemungkinan kebangkrutan perusahaan, formula ZScore untuk memprediksi kebangkrutan dari Altman merupakan sebuah multivariate formula yang digunakan dalam mengukur kesehatan finansial dari sebuah perusahaan.

Altman (1968) menggunakan metode Multiple Discriminant Analysis dengan lima jenis rasio keuangan yaitu working capital to total asset, retained earning to total asset, earning before interest and taxes to total asset, market value of equity to book value of total debts, dan sales to total asset. Dalam penelitian ini, Altman menggunakan 66 sebagai sampel perusahaan yang sudah terbagi masingmasing 33 sampel perusahaan yang dikategorikan sebagai perusahaan bangkrut dan 33 sampel perusahaan yang dikategorikan dalam perusahaan tidak bangkrut. Hasil pengolahan 33 sampel perusahaan oleh Altman ternyata membawa hasil, yang dimana hasil tersebut mempunyai tingkat keakuratan 95\% untuk data perusahaan satu tahun sebelum terjadinya kebangkrutan. Untuk data dua tahun sebelum kebangkrutan $72 \%$. Selain itu, dijelaskan juga bahwa perusahaan yang mempunyai nilai profit rendah bisa sangat berpotensi terjadinya collapse. Para peneliti sampai saat ini masih banyak yang menggunakan teori $Z$ Score dalam meneliti penelitiannya dibandingkan dengan teori yang lain. Persamaan diskriminan model Altman sebagai berikut : 
$Z=1,2 X 1+1,4 X 2+3,3 X 3+0,6 X 4+$ $0,999 \times 5$

Di mana:

$\mathrm{X} 1=$ Working Capital $/$ Total Asset

$\mathrm{X} 2=$ Retained Earnings $/$ Total Asset

$\mathrm{X} 3$ = Earning Before Interest and Taxes /

Total Asset

$\mathrm{X} 4$ = Market Value of Equity / Book Value of Total Debt

$\mathrm{X} 5$ = Sales / Total asset

Ciri perusahaan yang masuk dalam kategori bangkrut atau tidak berdasarkan dengan teori Z-Score dalam model yang digunakan Altman, yakni:

1. Jika nilai $Z$ lebih kecil dari 1,81 maka perusahaan yang diteliti laporan keuangannya tersebut masuk dalam kategori collapse.

2. Jika nilai $Z$ antara 1,81 dan 2,99 maka perusahaan yang telah diteliti laporan keuangannya tersebut masuk dalam kategori Grey Area (kritis).

3. Jika nilai $\mathrm{Z}$ lebih besar dari 2,99 maka perusahaan yang telah diteliti laporan keuangannya tersebut termasuk dalam kategori perusahaan sehat.

Grover Score, Model Grover muncul karena adanya pendesainan serta evaluasi ulang terhadap teori Altman dan Jeffery. Grover memakai ilustrasi sesuai dengan model Altman Z-Score tahun 1968, dengan menaikkan 13 rasio keuangan baru. Ilustrasi yang digunakan sebanyak 70 industri dengan 35 industri yang bangkrut serta 35 industri yang dalam kategori sehat pada tahun 1982 hingga 1996 serta menciptakan guna bagaikan berikut:

G-Score $=1,650 \mathrm{X} 1+3,404 \times 2-0$, 016ROA+ 0, 057

Di mana:

$\mathrm{X} 1=$ Working Capital/ Total Asset

$\mathrm{X} 2=$ Earnings Before Interest and Taxes/ Total Asset
$\mathrm{ROA}=$ Net Income/ Total Asset

Dalam teori Grover dikategorikan industri termasuk kondisi collaps dengan hasil kurang ataupun sama dengan -0,02 $($ Gram $\leq-0,02)$. Sebaliknya hasil untuk industri yang termasuk kondisi sehat yakni lebih atau sama dengan 0,01 (Gram $\geq 0,01$ ).

Zmijewski Score, Ekspansi penelitian dalam memprediksi terjadinya collapse pada perusahaan dilakukan oleh Zmijewski (1984) menaikkan validitas rasio keuangan bagaikan perlengkapan mendeteksi keuangan industri. Zmijewski melaksanakan penelitian dengan mengolah ulang riset bidang perusahaan yang mengalami collapse dengan hasil studi tadinya sepanjang 20 tahun. Rasio keuangan diseleksi dari rasio-rasio keuangan riset sebelumnya serta diambil ilustrasi sebanyak 75 industri yang bangkrut, dan 3573 industri sehat sepanjang tahun 1972 hingga dengan 1978, penanda F- test terhadap rasio-rasio kelompok, Rate of Return, liquidity, leverage, turnover, fixed payment coverage, trends, firm size, serta stock return volatility, membuktikan terdapatnya perbandingan yang signifikan antara industri yang dikategorikan collapse dan tidak collapse. Dengan kriteria evaluasi terus menjadi besar nilai $\mathrm{X}$ hingga terus menjadi besar mungkin/ probabilita industri tersebut bangkrut. Model yang sukses dikembangkan adalah: $\mathrm{X}$-Score $=-4,3-4,5 \mathrm{X} 1+5,7 \mathrm{X} 2-0$, 004X3

Di mana:

$\mathrm{X} 1=\mathrm{ROA}($ Return On Asset $)$

$\mathrm{X} 2=$ Laverage $($ Debt Ratio $)$

X3= Likuiditas( Current Ratio)

Nilai cut off yang ada pada model ini merupakan 0 . Hal ini berarti industri yang nilai $X$ lebih besar dari ataupun sama dengan 0 hingga diprediksi akan 
mengalami collapse di masa mendatang. Kebalikannya, industri yang mempunyai nilai lebih kecil dari 0 hingga diprediksi tidak dalam kondisi bangkrut. Zmijewski mempunyai nilai keakuratan dalam hal menganalisa laporan keuangan perusahaan sebesar 94,9\%.

\section{METODE PENELITIAN}

\section{Jenis Penelitian}

Jenis penelitian ini adalah penelitian kualitatif yang sepenuhnya menggunakan data sekunder berupa data keuangan perusahaan manufaktur yang menjadi sampel penelitian. Data ini bersumber dari laporan keuangan tahunan yang dipublikasikan oleh perusahaanperusahaan yang terdaftar di Bursa Efek Indonesia (BEI) sejak tahun 2015 sampai 2018. Jenis laporan keuangan yang menjadi sumber data meliputi neraca, laporan laba rugi, dan laporan arus kas yang diakses melalui website BEI: www.idx.co.id.

\section{Populasi dan Sampel Penelitian}

Populasi dalam penelitian ini merupakan seluruh perusahaan manufaktur yang terdaftar di Bursa Efek Indonesia (BEI) tahun 2015-2018. Pengambilan sampel penelitian ini menggunakan purposive sampling dengan kriteria sebagai berikut:

1. Perusahaan manufaktur yang terdaftar di BEI pada periode 2015-2018.

2. Perusahaan manufaktur yang delisting di BEI periode 2015-2018.

3. Perusahaan manufaktur yang tidak mempublikasikan laporan keuangan secara berturut-turut pada periode 2015-2018.

4. Perusahaan manufaktur yang tidak memiliki laba positif pada periode 2015-2018.

\section{Teknik Analisis Data}

Teknik menganalisis data pada penelitian ini adalah dengan menggunakan pendekatan kuantitatif. Untuk membantu analisis data, peneliti mengolah data dengan menggunakan software Microsoft Excel dan menyajikan data dalam bentuk tabel sebagai analisis yang digunakan untuk menarik kesimpulan sebagai dasar pengambilan keputusan.

Keadaan perusahaan dibagi menjadi dua jenis yaitu, pertama adalah perusahaan-perusahaan yang menghadapi financial distress yang disajikan dalam wujud variabel dummy dengan dimensi binomial $1(\mathrm{Y}=1)$ ialah perusahaan yang selama dua tahun berturut-turut menghadapi kerugian ataupun memiliki laba negatif; Kedua adalah perusahaanperusahaan yang tidak menghadapi financial distress $(\mathrm{Y}=0)$ ialah perusahaan yang selama dua tahun berturut- turut memiliki laba positif.

\section{HASIL DAN PEMBAHASAN}

\section{Penerapan Altman Score Terhadap Financial Distress}

Berdasarkan penelitian pada 16 perusahaan manufaktur pada periode 2015-2018 menggunakan model Altman Score dengan persamaan $\mathrm{Z}=1,2 \mathrm{X} 1+$ $1,4 \mathrm{X} 2+3,3 \mathrm{X} 3+0,6 \mathrm{X} 4+0,999 \mathrm{X} 5$ diperoleh hasil yaitu terdapat 7 perusahaan yang termasuk dalam kondisi sehat, 4 perusahaan dalam kondisi bangkrut (financial distress) dan 5 perusahaan dalam kondisi kritis (grey area). Sehingga model Altman Score dapat digunakan dalam memprediksi financial distress yang dimana hasil ini konsisten dengan penelitian terdahulu Hartono (2019), Andrianti (2016), dimana penelitian ini dengan tiga kategori yaitu sehat, grey area, dan financiall distress hampir disetiap penelitian terdahulu terdapat syarat-syarat tersebut. 
Penerapan Grover Score Terhadap Financial Distress

Berdasarkan penelitian 16 perusahaan manufaktur pada periode 2015-2018 menggunakan model Grover Score dengan persamaan $\mathrm{G}-\mathrm{Score}=1,650 \mathrm{X} 1+$ 3,404X2 - 0,016ROA + 0,057 diperoleh hasil yaitu terdapat 15 perusahaan yang masuk dalam kategori sehat (tidak mengalami financial distress), dan terdapat 1 perusahaan yang mengalami bangkrut (financial distress).

Model Grover Score dapat digunakan untuk memprediksi Financiall Distress yang dimana hasil ini konsisten dengan penelitian terdahulu seperti Ni Made Evi (2013) dalam penelitiannya disimpulkan bahwa metode model grover score merupakan metode yang paling sesuai dan metode yang paling tepat dalam memprediksi kebangkrutan perusahaan.

\section{Penerapan Zmijewski Score Terhadap Financial Distress}

Berdasarkan penelitian 16 perusahaan manufaktur pada periode 2015-2018 menggunakan model Zmijewski Score dengan persamaan $\mathrm{X}=-4,3-4,5 \mathrm{X} 1+$ $5,7 \mathrm{X} 2-0,004 \mathrm{X} 3$ diperoleh hasil yaitu terdapat 8 perusahaan yang masuk dalam kategori sehat, dan 8 perusahaan termasuk dalam kategori bangkrut (financial distress).

Model Zmijewski Score dapat digunakan dalam memprediksi financiall distress yang dimana hasil ini konsisten dengan penelitian terdahulu Payman Imanzadeh (2011) dalam penelitiannya menyimpulkan bahwa model zmijewski score merupakan alat prediksi yang sesuai dalam menyimpulkan financiall distress dalam suatu perusahaan.

\section{Perhitungan Tingkat Akurasi dan Tipeerror}

Perhitungan tingkat akurasi digunakan untuk melihat hasil dari deteksi dan status perusahaan yang akan dibandingkan.
Tingkat akurasi ini digunakan untuk menghitung masing-masing model Altman Score, Grover Score, Zmijewski Score dengan rumus :

\section{Tingkat Akurasi = \\ Jumlah Prediksi $x \quad 100 \%$}

Jumlah sampel

Selain tingkat akurasi, dilakukan pula perhitungan untuk mengetahui presentase tipeerror dari ketiga model tersebut. Dalam penelitian ini peneliti menggunakan tippeerror dengan cara:

\section{Tipe Error = \\ Jumlah Kesalahan $\quad x \mathbf{1 0 0 \%}$ \\ Jumlah Sampel}

\section{a. Model Altman Score}

Perbandingan antara hasil deteksi dengan status perusahaan menggunakan Altman Score diperoleh hasil sebagai berikut.

Tabel 1. Tingkat Akurasi Model Altman

\begin{tabular}{|c|c|c|c|c|}
\hline Rekapitulasi & \multicolumn{3}{|c|}{ Deteksi } & Total \\
\hline & Bangkrut & $\begin{array}{c}\text { Grey } \\
\text { Area }\end{array}$ & Sehat & \\
\hline $\begin{array}{c}\text { Riil Bangkrut } \\
\text { (Delisting) }\end{array}$ & 4 & 5 & 7 & 16 \\
\hline Total & 4 & 5 & 7 & 16 \\
\hline $\begin{array}{c}\text { Tingkat } \\
\text { Akurasi }\end{array}$ & \multicolumn{4}{|c|}{$25 \%$} \\
\hline Tipe Error & \multicolumn{4}{|c|}{$43.75 \%$} \\
\hline Grey Area & \multicolumn{3}{|c|}{$31.25 \%$} \\
\hline
\end{tabular}

Dari tabel di atas, Model Altman Score memiliki tingkat akurasi sebesar 25\% berdasarkan analisis yang dilakukan pada 16 perusahaan. Tipe error dari hasil tabel di atas dengan menggunakan model Altman Score sebesar $43.75 \%$ dengan mendeteksi 7 perusahaan yang masuk dalam kategori sehat.

Perusahaan yang termasuk dalam posisi grey area tidak bisa dimaksukkan dalam perhitungan tingkat akurasi karena 
tidak bisa ditentukan apakah perusahaan tersebut dalam posisi sehat atau bangkrut. b. Model Grover Score

Perbandingan antara hasil deteksi dengan status perusahaan menggunakan Altman Score diperoleh hasil sebagai berikut.

Tabel 2. Tingkat Akurasi Model Grover

\begin{tabular}{|l|l|l|l|}
\hline Rekapitulasi & \multicolumn{2}{|c|}{ Deteksi } & Total \\
\hline & Bangkrut & Sehat & \\
\hline $\begin{array}{l}\text { Riil Bangkrut } \\
\text { (delisting) }\end{array}$ & 1 & 15 & 16 \\
\hline Total & 1 & 15 & 16 \\
\hline Tingkat Akurasi & \multicolumn{3}{|c|}{$\mathbf{6 . 2 5 \%}$} \\
\hline Tipe Error & $\mathbf{3 3 . 7 5 \%}$ \\
\hline
\end{tabular}

Berdasarkan tabel di atas, Model Grover Score memiliki tingkat akurasi sebesar $6.25 \%$ berdasarkan analisis yang dilakukan pada 16 perusahaan. Tipe error dari hasil tabel di atas dengan menggunakan model Altman Score sebesar $93.75 \%$ dengan mendeteksi 15 perusahaan yang masuk dalam kategori sehat.

\section{c. Model Zmijewski Score}

Perbandingan antara hasil deteksi dengan status perusahaan menggunakan Zmijewski Score diperoleh hasil sebagai berikut.

Tabel 3. Tingkat Akurasi Model

\begin{tabular}{|l|l|l|l|}
\hline \multicolumn{1}{|c|}{ Rekapitulasi } & \multicolumn{2}{|c|}{ Deteksi } & Total \\
\hline & Bangkrut & Sehat & \\
\hline $\begin{array}{l}\text { Riil Bangkrut } \\
\text { (delisting) }\end{array}$ & 8 & 8 & 16 \\
\hline Total & 8 & 8 & 16 \\
\hline $\begin{array}{l}\text { Tingkat } \\
\text { Akurasi }\end{array}$ & \multicolumn{3}{|c|}{$\mathbf{5 0 \%}$} \\
\hline Tipe Error1 & \multicolumn{3}{|c|}{$\mathbf{5 0 \%}$} \\
\hline
\end{tabular}

Berdasarkan tabel di atas, model Zmijewski memiliki tingkat akurasi maupun tipe error sebesar 50\% karena hasil deteksi perusahaan dalam posisi sehat maupun tidak sehat sama-sama ada 8 perusahaan.

Berdasarkan perhitungan tingkat akurasi serta tipe error, peneliti dapat mengetahui model mana yang paling tepat dalam mendeteksi kebangkrutan dengan ketiga model tersebut, yaitu model Altman Score, Grover Score, Zmijewski Score. Dengan melihat model mana yang memiliki tingkat akurasi tinggi dan tipe error rendah. Berikut adalah rangkuman hasil perhitungan dimunculkan pada tabel.

Tabel 4. Perbandingan Tingkat Akurasi Model Altman, Grover, dan Zmijewski

\begin{tabular}{|l|l|l|}
\hline Model & $\begin{array}{l}\text { Tingkat } \\
\text { Akurasi }\end{array}$ & $\begin{array}{l}\text { Tipe } \\
\text { Error }\end{array}$ \\
\hline Altman & $25 \%$ & $43.75 \%$ \\
\hline Grover & $6.25 \%$ & $93.75 \%$ \\
\hline Zmijewski & $50 \%$ & $50 \%$ \\
\hline
\end{tabular}

Berdasarkan tabel di atas, dapat diketahui bahwa model yang tepat dalam mendeteksi kebangkrutan adalah dengan mempunyai kriteria tingkat akurasi lebih besar dan tipe error lebih kecil. Dari ketiga model yakni Altman, Grover, Zmijewski yang paling tepat adalah model Zmijewski Score dengan berdasarkan tingkat akurasi sebesar $50 \%$ dan berdasarkan tipe error adalah model Altman dengan presentase sebesar $43,75 \%$.

\section{SIMPULAN}

a. Metode Altman Score, dalam memprediksi 16 perusahaan manufaktur dapat diketahui bahwa terdapat 7 perusahaan dalam kondisi sehat, 4 perusahaan dalam kondisi bangkrut (financiall distress), dan 5 perusahaan dalam kondisi rawan (grey area). 
b. Model Grover Score, dalam memprediksi 16 perusahaan manufaktur dapat diketahui bahwa terdapat 15 perusahaan dalam kondisi sehat, dan 1 perusahaan dalam kondisi bangkrut (financial distress).

c. Model Zmijewski Score, dalam memprediksi 16 perusahaan manufaktur dapat diketahui bahwa terdapat 8 perusahaan masuk dalam kategori sehat, dan 8 perusahaan masuk dalam kondisi bangkrut (financial distress).

d. Dari ketiga model yang paling tepat digunakan dalam mendeteksi kebangkrutan menurut hasil tingkat akurasi adalah model Zmijewski Score, dengan tingkat akurasi sebesar $50 \%$, sedangkan menurut tipe error adalah model Altman Score sebesar $45,75 \%$.

\section{IMPLIKASI}

Bagi peneliti selanjutnya yang meneliti masalah ini disarankan untuk menambah model yang lainnya guna untuk menambah wawasan serta memperdalam ilmu dalam menganalisa posisi keuangan perusahaan yang akan diteliti baik untuk memprediksi posisi keuangan sekarang ataupun untuk masa mendatang. Menambah model guna untuk mendeteksi terjadinya financial distress, misalnya beneish score dan model lainnya seperti Ohlson ataupun yang lainnya dapat dilakukan dengan memperbanyak acuan sampel yang mencakup laporan keuangan peruahaan yang lainnya guna membuktikan model mana yang bisa mendeteksi "financial distress".

Bagi perusahaan sebaiknya dalam mengoperasikan keuangannya harus secara teliti supaya tidak terjadi apa yang tidak diinginkan. Selain itu, pihak perusahaan juga harus benar-benar pintar dalam hal mengelola keuangannya serta melakukan evaluasi untuk

mengoptimalkan kinerja keuangan perusahaan yang dapat menyebabkan financial distress bahkan kebangkrutan.

\section{REFERENSI}

Alimiansyah dan pandji, 2003. Kamus Istilah Keuangan dan Perbankan, Bandung: Yrama Widya.

Andriyanti, 2016. "Analisis Ketepatan Model Altman, Springate, Zmijewski, Ohlson, dan Grover Sebagai Detektor Kebangkrutan", UIN Maulana Malik Ibrahim, Malang.

Dwi Prastowo dan Rifka Julianty, 2005. Analisis Laporan Keuangan Konsep Aplikasi, Yogyakarta.

Fajriah, L. R., 2015. Ini Saran Bos IMF untuk Dongkrak Ekonomi Indonesia. Diambil 30 Juni 2021, dari https://ekbis.sindonews.com/berita/10 39765/33/ini-saran-bos-imf-untukdongkrak-ekonomi-indonesia

Gege Adi Prasetyo, 2005. Penyusunan \& Analisis Laporan Keuangan Pemerintah Daerah, Yogyakarta.

Ghufron Mas'adi, 2002. Fiqh Muamalah Kontekstual, Jakarta.

Hamka. 1983. "Tafsir Al-Azhar Juz lll”. Jakarta: Pustaka panjimas, hal. 104.

Hantono, 2019. Memprediksi Financial Distress Dengan Menggunakan Model Altman Score, Grover Score, Zmijewski Score (Studi Kasus Pada Perusahaan Perbankan) tahun 20132017, Jurnal Riset Akuntansi Going Concern 1, Universias Prima Indonesia, medan.

Mamduh Hanafi dan Abdul Halim, 2005. Analisis Laporan Keuangan, Yogyakarta.

Munawir, 2004. Analisa Laporan Keuangan, Yogyakarta. 
Ni Made Evi, 2013. "Prediksi Kebangkrutan Dengan Model Grover, Altman Z-Score, Springate, dan Zmijewski Pada Perusahaan Food And Beverage Di Bursa Efek Indonesia", Fakultas Ekonomi dan Bisnis Universitas Udayana, Bali, Indonesia. Imanzadeh, Payman, 2011. "A Study of the Application of Springate and Zmijewski Bankruptcy Prediction Models in Firms Accepted in Tehran Stock Exchange", Islamic Azad University, Talesh, Iran. 